\title{
Erratum to: A novel analytical solution for the modified Kawahara equation using the residual power series method
}

\author{
Bewar A. Mahmood - Majeed A. Yousif
}

Published online: 24 April 2017

(C) Springer Science+Business Media Dordrecht 2017

\section{Erratum to: Nonlinear Dyn \\ DOI 10.1007/s11071-017-3512-3}

In Eqs. (3) and (7) in the original publication, duplication errors were introduced at the proofs stage. The correct equations are shown below.

$\Psi(x, t)=g(t),(x, t) \in \partial D \times[0, T]$

$\Psi_{m}(x, t)=f_{m}(x) t^{m}, \quad m=0,1,2, \ldots$,

The online version of the original article can be found under doi:10.1007/s11071-017-3512-3.

B. A. Mahmood ( $\square)$

Department of Mathematics, Faculty of Science, University of Duhok, Dohuk, Kurdistan Region, Iraq e-mail: b.m.numerical@uod.ac

M. A. Yousif

Department of Mathematics, Faculty of Science, University of Zakho, International Road Zakho-Duhok,

P.O. Box 12, Duhok, Kurdistan Region, Iraq

e-mail: majeed.ahmed@uod.ac 